\title{
EHMTI-0298. Relationship between migraine and abnormal EEG findings in children
}

\author{
P Karimzadeh \\ From 4th European Headache and Migraine Trust International Congress: EHMTIC 2014 \\ Copenhagen, Denmark. 18-21 September 2014
}

\section{Introduction}

Migraine is a disabling illness that causes absence from school and affects the quality of life. It has been stated that headache may represent an epileptic event. EEG abnormality is a prominent finding in children with migraine.

\section{Aim}

The aim of this study was to evaluate EEG abnormalities in children with migraine.

\section{Materials and methods}

Two-hundred twenty-eight children were enrolled into the study. Evaluation and following of cases was performed by one physician, paraclinical tests were used to increase the accuracy. The study was conducted under the supervision of pediatric neurology masters and the selected cases were from different parts of the country.

\section{Results}

Comparing EEG abnormalities in different types of migraine revealed that there is an association between them. There was also a significant difference between EEG abnormalities in different types of aura. Migraine type was associated with the patient's age. Sleep disorders were more common in patients with a positive family history of seizure.

\section{Conclusions}

Our study disclosed migraine as a common problem in children with abnormalities present in approximately $20 \%$ of the patients. Migraine and abnormal EEG findings are significantly associated.

No conflict of interest.

Pediatric Neurology, shahid Beheshti Medical University, Tehran, Iran
Published: 18 September 2014

doi:10.1186/1129-2377-15-S1-B16

Cite this article as: Karimzadeh: EHMTI-0298. Relationship between migraine and abnormal EEG findings in children. The Journal of Headache and Pain 2014 15(Suppl 1):B16.
Submit your manuscript to a SpringerOpen ${ }^{\bullet}$ journal and benefit from:

- Convenient online submission

- Rigorous peer review

- Immediate publication on acceptance

- Open access: articles freely available online

- High visibility within the field

- Retaining the copyright to your article

Submit your next manuscript at $\gg$ springeropen.com (c) 2014 Karimzadeh; licensee Springer. This is an Open Access article distributed under the terms of the Creative Commons Attribution License (http://creativecommons.org/licenses/by/2.0), which permits unrestricted use, distribution, and reproduction in any medium, provided the original work is properly cited. 